UDC 004.35: 004.9

\title{
Model and hardware-software implementation of information processing system for psychophysical and psychophysiological researches
}

\author{
N.V. Varlamova ${ }^{1}$, V.T. Lazurik ${ }^{2}$, N.G. Styervoedov ${ }^{3}$ \\ ${ }^{l}$ V. N. Karazin Kharkiv National University, 6 Svobody Sq., Kharkiv, 61022, Ukraine \\ ${ }^{2}$ V. N. Karazin Kharkiv National University, 6 Svobody Sq., Kharkiv, 61022, Ukraine \\ ${ }^{3}$ V. N. Karazin Kharkiv National University, 6 Svobody Sq., Kharkiv, 61022, Ukraine \\ e-mail:natess123@gmail.com
}

The conceptual model of the information processing system for psychophysical and psychophysiological researches has been developed. The hardware-software implementation of this system will allow us to diagnose a person's mental state on site or remotely, to identify person's professional suitability, to measure psychophysiological and cognitive characteristics, to store and process research information using the cloud service. The structure of the information processing system model is represented by UML diagrams. The detailed plan of the information processing system realization is presented.

Keywords: information processing system, UML diagram, psychological research, microcontroller, remote control, cloud service, mobile application.

Разработана концептуальная модель информационно-измерительной системы для психофизических и психофизиологических исследований. Аппаратно-программная реализация этой системы позволит локально и удаленно проводить диагностику психического состояния человека, выявлять ее профессиональной пригодности, измерять психофизиологические и когнитивные характеристики, хранить и обрабатывать информацию об исследовании, используя преимущества облачного сервиса. Структура модели информационно-измерительной системы изображена с помощью диаграмм UML. Представлен подробный план реализации информационно-измерительной системы.

Ключевые слова: информационно-измерительная система, UML диаграмма, психологические исследования, микроконтроллер,дистанционное управление, облачный сервис, мобильное приложение.

Розглянуто важливість застосування спеціалізованих програмно-апаратних комплексів з батареями психодіагностичних тестів для психофізіологічного та психофізичного моніторингу. Описано проблему нестачі сучасних інформаційних технологій для побудови систем якісної психодіагностики, особливо тих, що дозволяють проводити дистанційне обстеження. Доведена актуальність створення інформаційно-вимірювальної системи, що має сучасні способи отримання, передачі, обробки та збереження даних. Розроблено концептуальну модель інформаційно-вимірювальної системи для психофізичних і психофізіологічних досліджень. Апаратно-програмна реалізація цієї системи дозволить локально і віддалено проводити діагностику психічного стану людини, виявляти ії професійну придатність, вимірювати психофізіологічні та когнітивні характеристики, зберігати та обробляти інформацію про дослідження, використовуючи переваги хмарного сервісу та мобільного додатку. Структура моделі інформаційно-вимірювальної системи зображена за допомогою діаграм UML. Структурна модель представлена чотирма блоками: блоком управління (робоче місце експерта), блоком тестування (робоче місце досліджуваного), блоком отримання і передачі даних та блоком обробки та збереження даних. UML діаграми відображають як склад кожного блоку, так і способи взаємодії між компонентами системи. Представлений детальний план реалізації інформаційно-вимірювальної системи. Наведений короткий опис: способу налаштування та з'єднання Wi-Fi модулю ESP8266 із мікроконтролером STM32F4, принципи роботи хмарного сервісу ThingSpeak. Описані функції мобільного додатку інформаційно-вимірювальної системи.

Ключові слова: інформачійно-вимірювальна система, UML діаграма, психологічні дослідження, мікроконтролер, дистаниійне керування, хмарний сервіс, мобільний додаток.

\section{Problem statement}

Obtaining objective and reliable information on the professional suitability of the operator of complex systems and processes as well as the actual functional and psychological state of the employees and their ability to perform responsible or monotonous work is of high priority in the workplace safety and health management. Being ready to rapidly take action on basis of that information is a prerequisite for the effective management of the task assigned to the individual or executive team. The identification of the individual characteristics of an employee's job and the ability to assess the probability of an impending event is the basis for the optimal distribution of staff in any team. The sources of such information are specialized software-hardware complexes for psychophysiological monitoring by means of sets of psychological tests [1 - 3].

The development of models, logical flowcharts, algorithms and computer programs for psychophysiological research requires a detailed study of the psychological, physiological, and moral aspects of the problem, as well as professional experience with information technologies, electronic equipment and programming languages. Despite the growing need for such research and the relevance of computer-assisted psychophysiological diagnostics, the present information processing systems are 
extremely insufficient, and their functionality is significantly limited. This is particularly true for systems that allow remote monitoring. For example, remote monitoring of the psycho-emotional state of truck drivers, diagnosing the functional state of athletes and military personnel determine their readiness to perform complex and responsible work.

Therefore, the development of information processing systems for psychophysical and psychophysiological studies that meet modern requirements is an urgent task $[4,5]$. The urgency of creating and using information systems in psychophysiological and psychological research is determined by the fact that nowadays a person's information load has considerably increased. As a result, stressful situations, the need for ambiguous decisions, and the need to find solutions in an uncertain environment are increasingly occurring. The active use of specialized software-hardware systems for psychophysical training could contribute to the adaptation of human behavior in the context of information noise and global digital transformation of society. Obviously, the citizens' mental health depends on the effectiveness of implementation and usage of such systems.

The Internet, modern information technologies and electronic environment offer new opportunities for building more advanced psychodiagnostic systems.

The proposed development of a new generation of specialized information processing system is aimed at fast and effective psychological support for decision-making, diagnostics and control (including remote control) of psychophysiological state and cognitive abilities of a person.

\section{Conceptual model of information processing system for psychophysical and psychophysiological researches}

The presented information processing system has the following features: it provides end-to-end information support for psychological research at all stages of the information flow based on integrated data presented in a unified form, information storage, visualization and data protection. The significant advantages of the system are the usage of cloud services in the process of data collection and processing, the ability to easily change and expand both the devices for the tests and the tests themselves, to work with various network technologies, as well as to engage, by the mobile application, professional psychologists and experts specializing in the subject areas.

In addition, the form and method of presenting information during the research process can be adaptively reshaped in the system. Thus, the functionality of the system can be described by the following levels: 1 - collection, registration and structuring of information, creation of information space; 2 - storage and search of additional information, set up of information exchange; 3 - statistical analysis of data, decision support and synthesis of test effects.

Let us consider the structure of the conceptual model of the information processing system, which is represented as a UML diagram of components.

Fig. 1 shows the information processing system consisting of the following units: the control unit (essentially, workplace expert), the testing unit (workplace investigated), the unit for receiving and transmitting data, and the unit for processing and storage data.

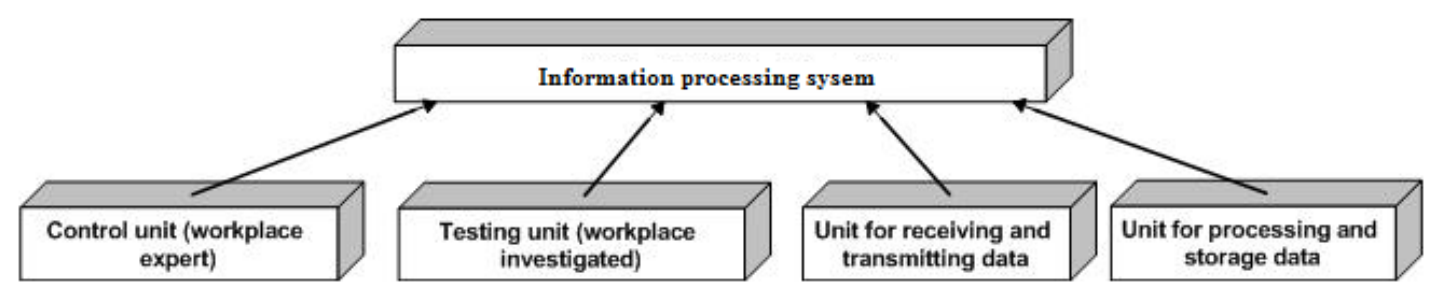

Fig. 1. Information processing system for psychophysiological research

Fig. 2a is a diagram of the components of the control unit (workplace expert) consisting of a PC communicating through the mobile application interface with the mobile application, and the testing unit (workplace investigated) containing the diagnostic unit which feeds through the adapter from the $9 \mathrm{~V}$ power supply unit (Fig. 2b). 
Fig. 3a presents a diagram of unit for receiving and transmitting data, comprising an STM32F4 microcontroller and an ESP8266 Wi-Fi module, that interact with each other through AT-commands, and a router that is connected through TCP / IP communication protocols. In the absence of the Internet, mobile communication or recording on a built-in fixed memory can be used with subsequent data transmission to the cloud-based subsystem of reception, processing and storage.

The unit for processing and storage data, presented in Fig. 3b, consists of a database management system (DBMS), the database itself, and a ThingSpeak cloud server.

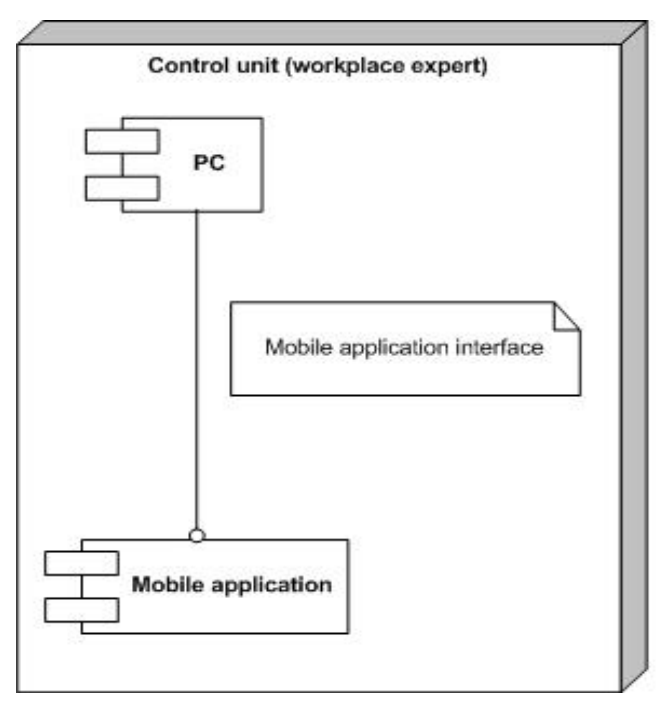

a)

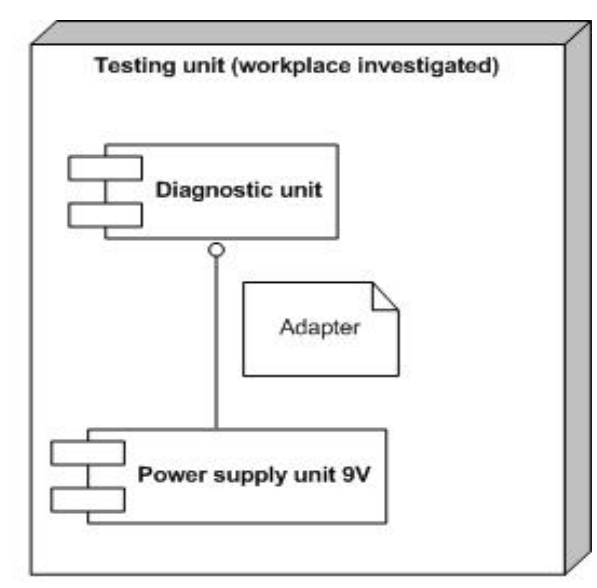

b)

Fig. 2 UML diagrams of the control unit (a) and the testing unit (b)

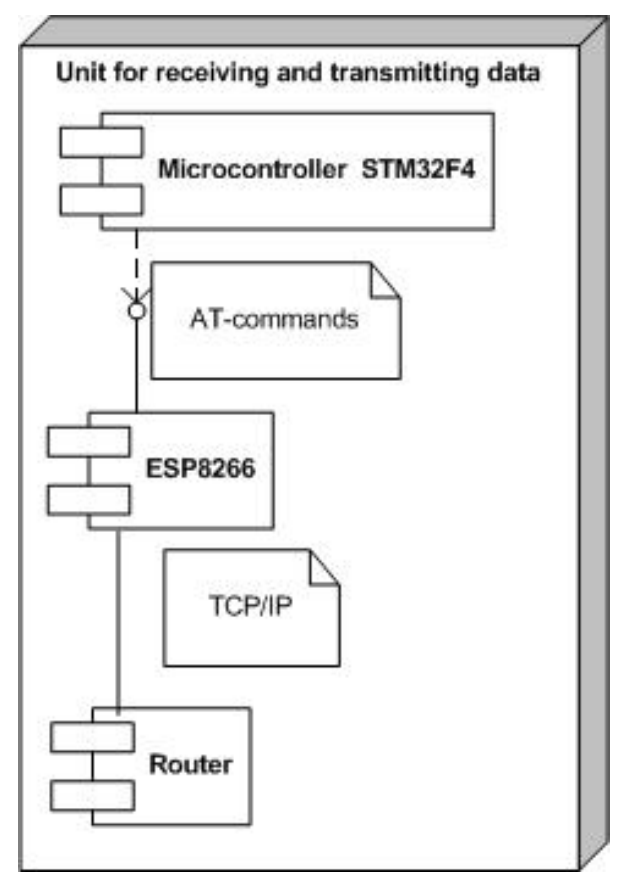

a)

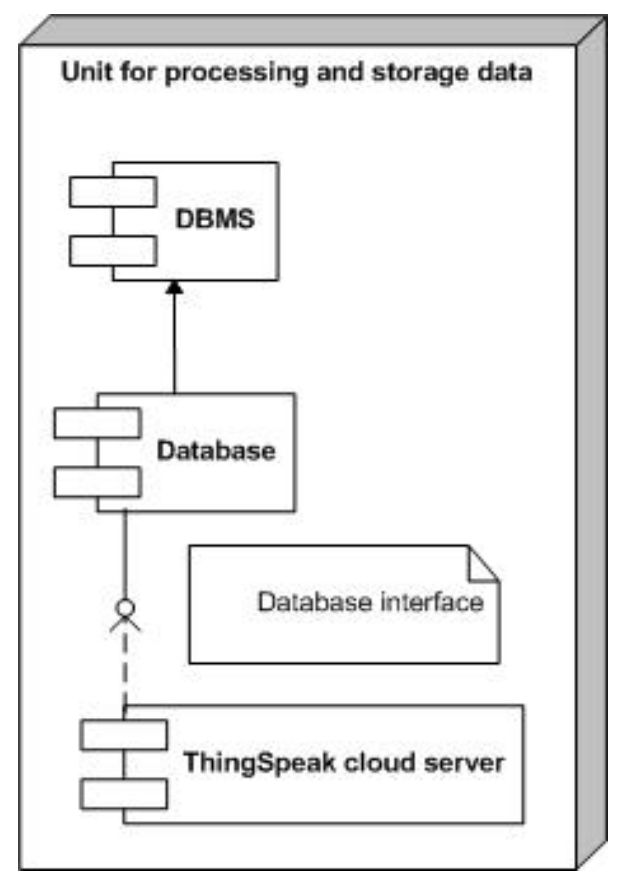

b)

Fig. 3. UML Diagrams of the Unit for Receiving and Transmitting Data (a) and the Unit for Processing and Storage Data (b)

Fig. 4 shows the general structure of the conceptual model of the information processing system for psychophysiological research. The developed model describes the processing and analyzing data remotely in real time. The general structure presents not only all the components, but the functional 
connections between the components as well: the mobile application and the ThingSpeak cloud server interact through the ThingSpeak interface, and the mobile application and the DBMS interact through the DBMS interface respectively. Data transmission between the router and the ThingSpeak cloud server is possible within HTTP requests. The connection of the diagnostic unit to the STM32F4 microcontroller and its efficient functioning are possible due to the IDE libraries included in the basic STM32F4.

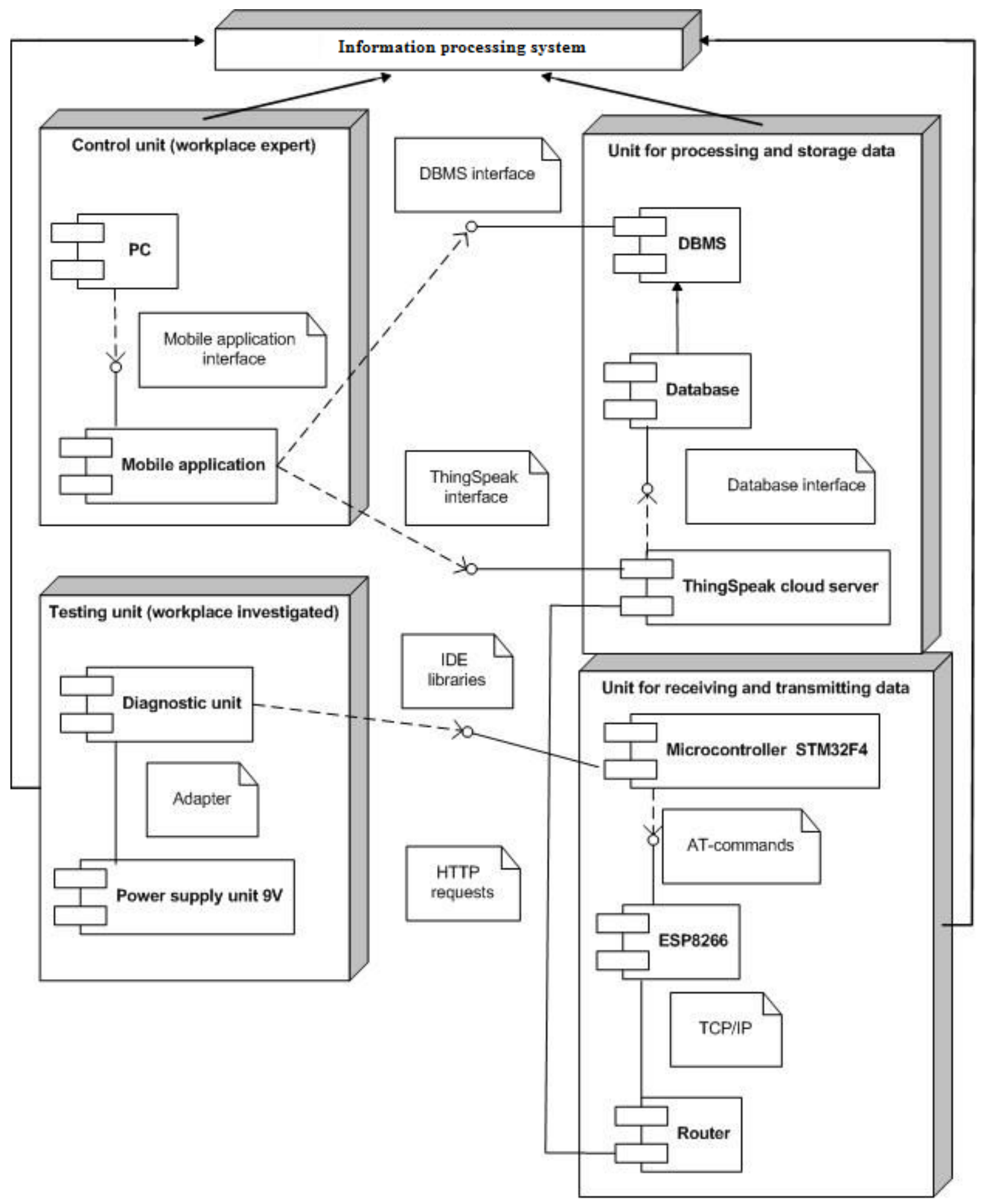

Fig 4. UML diagram "Conceptual model and hardware-software implementation of information processing system for psychophysiological researches" 


\section{System model implementation}

The steps planned for the system model implementation are:

1. Installation and testing of the diagnostic unit

2. Installation, configuration, connection and testing of ESP-8266

3. Configuration of the ThingSpeak Status Channel

4. Install ThingSpeak code on STM32F4

5. Database development

6. Development of Android application

7. Installation and configuration of external devices

8. Configuration of the ThingSpeak Actuators channels

9. Configuration of the STM32F4 with external devices

10. Testing Android application with sensor status check

11. General testing of the hardware-software complex.

To connect sensors it is necessary to use certain libraries native to STM32 IDE. These libraries make it possible to initiate sensors, obtain sensor readings and display them on the monitor screen.

The use of ESP8266-12 requires the usage of AT-commands (the module includes an AT-commands processor). To connect the module and adjust the rate of data transfer, it is necessary to connect STM32F4 to the PC, use empty code and AT commands in the open IDE. The final connection to the already configured ESP8266-12 includes the following connections:

- ESP-12 RXD --> STM32F4 PIN PD6

- ESP-12 TXD --> STM32F4 PIN PD4

- ESP-12 Ch-Pd (En) --> Vcc (3.3V)

- ESP-12 Reset --> STM32F4 Pin PB5

- ESP-12 Vcc (Red) --> 3.3V

- ESP-12 Gnd (Black) --> STM32F4 PIN PC15

The next step after installing the sensors and connecting the ESP-8266 is to configure the process of transmitting information from the sensors to the cloud service. ThingSpeak's cloud service allows collecting information from the sensors, as well as processing and analyzing it. After registration on Thingspeak, channels responsible for collecting sensor data (keyboards) and controlling actuators (visual stimulus unit) through the mobile application are created. HTTP requests are required to transmit data to the cloud. For example, to record data in the Status Channel fields (at a frequency of 1 every 15 seconds), it is necessary to submit an HTTP GET request.

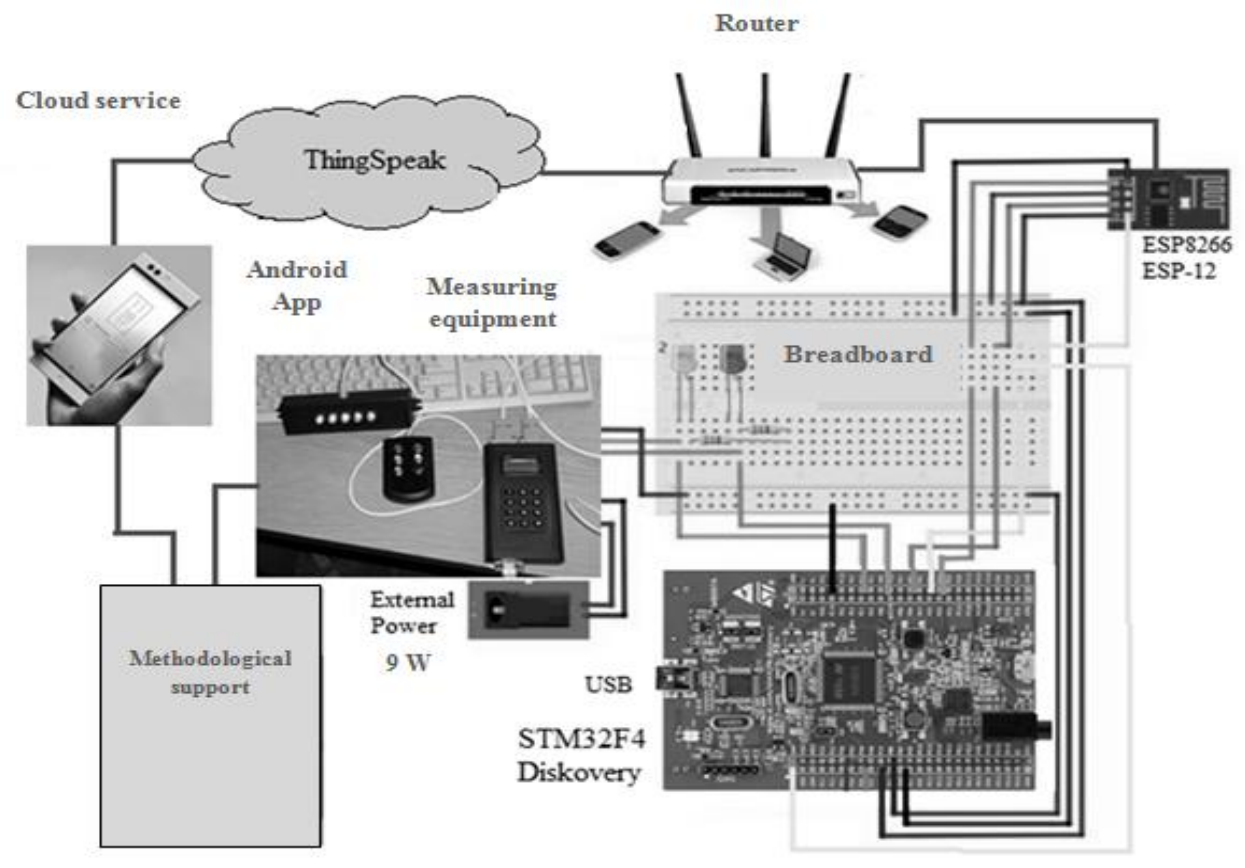

Fig. 5 Current layout of the subsystem for receiving and transmitting data for remote monitoring. 
The mobile application of the hardware-software complex allows not only remote controlling of the executive devices (turn on, turn off, select the mode of the methodology) and viewing the information received from the sensors through the cloud server Thingspeak, but also drawing the initial and final expert conclusions on the diagnostics of the investigated personnel and storing them in the database. A significant advantage of the ThingSpeak cloud is the availability of a powerful suite of applications for solving scientific and technical computing problems (MatLab) which can perform all necessary data operations [6,7].

The structural and functional organization of the current layout of the subsystem of receiving and transmitting data for remote monitoring of psycho-emotional state is shown in Fig. 5. The subsystem layout is made on the basis of the STM32F4 Discovery microcontroller board. The board is connected to one of the information-executive modules of the psychodiagnostic system (described in [8]), the Wi-Fi module ESP8266-12 and the power adapter.

\section{Conclusions}

The conceptual model of the information processing system for studying of psychophysical and psychophysiological patterns of sensory processes of a person is presented in the article. The model is a framework of functional blocks, the inputs and outputs of which are connected through the appropriate interfaces. It is presented as UML diagrams of general structure and detailed diagrams of system components. Such presentation made it possible to qualitatively and clearly visualize the structure and describe the system operation principles. Building a conceptual model greatly simplifies the next stages of designing an information processing system. The basic stages of implementation have been developed and described on the basis of the model of real information processing system with the possibility of both local and remote research of psychophysical and psychophysiological functions.

\section{REFERENCES}

1. V. D. Balin, V. K. Gaida, V. K. Gerbachevsky, et al. Praktikum po obshchey, eksperimental'noy $i$ prikladnoy psikhologii. St. Petersburg: Piter, 2003. 560 p. [In Russian].

2. V. V. Kal'nish, A. I. Yena. "Pryntsypy profesiynoho psykhofiziolohichnoho vidboru [Principles of professional psychophysiological selection]”. Journal of Hygiene of Labor, Vol. 32, pp.131-144, 2001. [In Ukrainian].

3. M.A. Popova, I. V. Myl'chenko, A.E. Shcherbakova, R.M.Safin. "Funktsional'noye sostoyaniye vegetativnoy i tsentral'noy nervnoy sistemy u lits, zanimayushchikhsya ekstremal'nymi vidami sporta" [The functional state of the autonomic and central nervous system in persons engaged in extreme sports]. Modern problems of science and education, No. 3, 2013. URL: https://www.scienceeducation.ru/ru/article/view?id=9240. Accessed on: 25.10.2019. [in Russian]

4. M. L.Kochina, A. G. Firsov. "Mnogofunktsional'nyy pribor dlya provedeniya psikhofiziologicheskikh issledovaniy [Multifunctional device for psychophysiological research]". Applied radio electronics. Vol. 9, No 2, pp. 260-265, 2010. [In Russian].

5. P.V. Belichenko, N.V. Blaginya, A.V. Mal'tsev, M.M. Khruslov. "Apparatno-programmnoye obespecheniye v psikhologii [Hardware and software in psychology]". Computer modeling in hightech technologies. pp. 22-25, 2014. [In Russian].

6. P. L. Nikolaev. "Primeneniye oblachnykh tekhnologiy v sistemakh umnogo doma [The use of cloud technologies in smart home systems]". Scientific journal "Young Scientist, No. 13, pp. 37-39, 2014. URL: https://moluch.ru/archive/72/12306/. Accessed on: 20.10.2019. [In Russian]

7. ThingSpeak. (2017). [Online]. URL: https://thingspeak.com/. Accessed on: 09.10.2019.

8. N.V. Varlamova, N.G. Styervoyedov. "Hardware - software complex for psychological and professional diagnostics with the remote control function". Bulletin of V. Karazin Kharkiv National University, series Mathematical Modelling. Information Technology. Automated Control Systems, Vol. 38, pp. $25-32,2018$.

\section{ЛІТЕРАТУРА}

1. Балин В. Д., Гайда В. К., Гербачевский В. К. и др. Практикум по общей, экспериментальной и прикладной психологи./ Под общей ред. А. А. Крылова, С. А. Маничева. Питер: 2-е изд., доп. и перераб. СПб., 2003. 560 с.

2. Кальніш В. В., Єна А. І. Принципи професійного психофізіологічного відбору. Гігієна праці. Київ, 2001. Вип. 32. С.131-144. 
3. Попова М.А., Мыльченко И. В., Щербакова А.Э., Сафин Р.М. Функциональное состояние вегетативной и центральной нервной системы у лиц, занимающихся экстремальными видами спорта. Современные проблемы науки и образования. 2013. № 3. URL: https://www.scienceeducation.ru/ru/article/view?id=9240 (дата звернення 25.10.2019)

4. Кочина М. Л., Фирсов А. Г. Многофункциональный прибор для проведения психофизиологических исследований. Прикладная радиоэлектроника, 2010. Т.9, №2. С.260265.

5. Беличенко П.В., Благиня Н.В., Мальцев А.В., Хруслов М.М. Аппаратно-программное обеспечение в психологии. Труды международной науч.-техн. конф. Харьков: ХНУ м. В.Н.Каразина, 2014. С. 22-25.

6. Николаев П. Л. Применение облачных технологий в системах умного дома. Научный журнал «Молодой ученый». 2014. Вып. 13. С. 37-39. URL: https://moluch.ru/archive/72/12306/ (дата звернення 20.10.2019).

7. Хмарний сервер ThingSpeak. [Електроний pecypc]. URL: https://thingspeak.com/ (Дата звернення: 09.10.2019)

8. Varlamova N.V., Styervoyedov N.G. Hardware - software complex for psychological and professional diagnostics with the remote control function. Вісник Харківського національного університету імені В.Н. Каразіна, серія «Математичне моделювання. Інформаційні технології. Автоматизовані системи управління». 2018. Вип. 38. С.25 - 32.

Varlamova Natalia V. - Post - graduate student of Department of Computer Science Faculty, V. N. Karasin Kharkiv National University, Svobody Sq 6, 61022, Kharkiv, Ukraine, natess123@ gmail.com; ORCID: 0000-0001-5117-7293

Lazurik Valentine T.- doctor of physical and mathematical sciences, professor; Dean of Computer science faculty; V.N. Karazin Kharkiv National University, Ukraine, 61022, Kharkiv, Svobody Sq., 6; e-mail:vtlazurik@karazin.ua; ORCID: 0000-0002-8319-0764.

Styervoyedov Nicolay G. - PhD (Technology), Associate Professor: Head of Electronics and Control Systems Department V. N. Karasin Kharkiv National University, Svobody Sq 6, 61022, Kharkiv, Ukraine,n.styervoyedov@karazin.ua, keus@karazin.ua; ORCID: 0000-0003-0136-6437.

Варламова Наталя Володимирівна - аспірант факультету комп'ютерних наук; Харківський національний університет імені В. Н. Каразіна, майдан Свободи, 6, Харків-22, Украйна, 61022;

e-mail: natess123@gmail.com; ORCID:0000-0001-5117-7293

Лазурик Валентин Тимофійович - доктор фізико-математичних наук, професор; декан факультету комп'ютерних наук; Харківський начіональний університет імені В. Н. Каразіна, майдан Свободи, 6, Харків-22, Украӥна, 61022; e-mail: vtlazurik@karazin.иa; ORCID: 0000-00028319-0764.

Стєрвосдов Микола Григорович - кандидат технічних наук, доиент; завідуючий кафедрою електроніки і управляючих систем, Харківський національний університет імені В. Н. Каразіна, майдан Свободи, 6, Харків-22, Україна, 61022;

e-mail: n.styervoyedov@karazin.ua, кeus@karazin.ua; ORCID:0000-0003-0136-6437.

Варламова Наталья Владимировна- аспирант факультета компьютерных наук; Харьковский национальный университет имени В. Н. Каразина, площадь Свободы, 6, Харьков-22, Украина, 61022; e-mail: natess123@gmail.com; ORCID:0000-0001-5117-7293

Лазурик Валентин Тимофеевич - доктор физико-математических наук, профессор; декан факультета компьютерных наук; Харьковский национальный университет имени В. Н. Каразина, площадь Свободьы, 6, Харьков-22, Украина, 61022; e-mail: vtlazurik@karazin.ua; ORCID: 00000002-8319-0764.

Стсрвосдов Микола Григорович - кандидат технических наук, дочент; заведующий кафедрой электроники и управляющих систем, Харьковский национальный университет имени B.Н. Каразина, площадь Свободы, 6, Харьков-22, Украина, 61022;е-таil: n.styervoyedov@karazin.ua, keus@karazin.ua; ORCID: 0000-0003-0136-6437. 